\title{
ATMIN wt Allele
}

National Cancer Institute

\section{Source}

National Cancer Institute. ATMIN wt Allele. NCI Thesaurus. Code C101291.

Human AT MIN wild-type allele is located in the vicinity of $16 \mathrm{q} 23.2$ and is approximately

$11 \mathrm{~kb}$ in length. This allele, which encodes AT M interactor protein, is involved in both DNA damage response and cell survival. 